\title{
$\begin{array}{ll}\text { Research Square } & \text { Preprints are preliminary reports that have not undergone peer review. }\end{array}$ or referenced by the media as validated information. \\ Formation of ColV $=0$ intermediate at the Boundary of the "Oxo-wall" Induces Water Oxidation
}

\section{Roman Ezhov}

Purdue University

\section{Alireza Ravari}

Purdue University

\section{Gabriel Bury}

Purdue University

\section{Paul Smith}

Valparaiso University

Yulia Pushkar ( $\nabla$ ypushkar@purdue.edu )

Purdue University

\section{Article}

Keywords: Artificial Photosynthesis, Cubane, Multimetallic Structure, Stabilization, Oxygen Evolution Catalysts

Posted Date: November 19th, 2020

DOI: https://doi.org/10.21203/rs.3.rs-93543/v1

License: (c) (i) This work is licensed under a Creative Commons Attribution 4.0 International License. Read Full License 


\section{Abstract}

Development of economically viable artificial photosynthesis requires use of $3 \mathrm{~d}$ metal-based catalysts. Water oxidation by $\left[\mathrm{Co}_{4} \mathrm{O}_{4}\right]^{\text {n+ }}$ cubane mimics water splitting by $\mathrm{CaMn}_{4} \mathrm{O}_{5}$ cluster in Nature but the exact mechanism of O-O bond formation is presently unknown. We demonstrate first in situ detection $\mathrm{CO}^{\mathrm{IV}}=\mathrm{O}$ $\left(\sim 1.67 \AA\right.$ ̊ ) moiety formed upon activation of $\left[\mathrm{Co}_{4} \mathrm{O}_{4} \mathrm{Py}_{4} \mathrm{Ac}_{4}\right]^{0}\left(\mathrm{Py}=\right.$ pyridine and $\left.\mathrm{Ac}=\mathrm{CH}_{3} \mathrm{COO}^{-}\right)$towards O$\mathrm{O}$ bond formation. Combined spectroscopic and DFT analyses show that the intermediate active in 0-O bond formation has two $\mathrm{Co}^{\mathrm{IV}}$ centers and at least one $\mathrm{Co}^{\mathrm{IV}}=\mathrm{O}$ unit of strong radicaloid character that participates in 0-O bond formation via water nucleophilic attack. The multimetallic structure of the cubane provides unique stabilization for $\mathrm{Co}^{\mathrm{IV}}=\mathrm{O}+\mathrm{H}_{2} \mathrm{O}=\mathrm{Co}-\mathrm{OOH}+\mathrm{H}^{+}$transition with the carboxyl accepting the proton and the bridging oxygen stabilizing the peroxide via hydrogen bonding. Results are important for development of oxygen evolution catalysts based on Earth-abundant 3d elements.

\section{Introduction}

Water splitting reaction is a keystone in application of solar energy for electrochemical water splitting to obtain hydrogen gas, a sustainable carbon-neutral energy source on an economic-wide scale. ${ }^{1}$ The ultimate goal in water oxidation catalysts design is to develop a material comparable with natural photosynthetic cluster $\mathrm{CaMn}_{4} \mathrm{O}_{5}$ in water-splitting efficiency. Currently, the most productive electrocatalysts for this process utilize noble metals due to their high stability, small overpotential, and low Tafel value. ${ }^{2,3}$ However, the application of precious metal-based catalysts on an industrial scale is cost prohibitive. To make this process more economically viable, oxygen evolution and reduction catalysts have been developed using cobalt and other Earth-abundant metals. 4, 5, 6, 7, 8, 9 Water oxidation reaction (WOR) electrocatalysts based on transition metal oxides were extensively studied. ${ }^{10,11,12} \mathrm{Co}$ cubanes bearing $\left[\mathrm{Co}_{4} \mathrm{O}_{4}\right]^{\mathrm{n}+}$ oxo-metalate cluster draw considerable attention, as they carry the minimal $\mathrm{Co}_{4} \mathrm{O}_{4}$ unit potentially present in the solid oxides but are tangible to the detailed mechanistic studies as the molecular systems. ${ }^{13,14,15,16,17,18,19}$ This motif is also similar to the $\mathrm{CaMn}_{4} \mathrm{O}_{5}$ oxygen evolving complex (OEC) of Photosystem II (PS II), responsible for water oxidation in natural photosynthesis $7,13,16$, ${ }^{20}$. Elucidating the mechanism of the $0-0$ bond formation in such catalysts is crucial to the development of economically viable artificial photosynthesis.

Several mechanisms of WOR have been proposed for Co-based complexes, including $\left[\mathrm{Co}_{4} \mathrm{O}_{4} \mathrm{Py}_{4} \mathrm{Ac}_{4}\right]^{0}$ (1) (Fig. 1a). ${ }^{13,14,15,16,17,21,22,23}$ (1) ${ }^{+}$or "cubium", is water-soluble in basic conditions and can oxidize water at $\mathrm{pH}=10$ and above with $\mathrm{O}_{2}$ and $\mathrm{H}^{+}$release. It was found that the crucial process necessary for $(1)^{+}-$promoted WOR catalytic cycle at basic $\mathrm{pH}$ is coordination of hydroxyl ion $\left(\mathrm{OH}^{-}\right)$to a Co center. ${ }^{14}$ Catalytic mechanisms of (1) have been studied using UV-Vis, EPR, mass-spectrometry, X-ray spectroscopy, DFT calculations, and $\mathrm{O}_{2}$ evolution measurements at different $\mathrm{pH}$ and with the use of isotopically-labelled reagents. ${ }^{14,22,24}$ Different conformations of the mixed $\mathrm{Co}^{\text {IV }} / \mathrm{Co}^{\text {IIII }}$ cubane 
intermediates and the 0-0 forming units have been discussed previously (Fig. 1b, c) but there remains no consensus on the mechanism. ${ }^{14,21,23}$ Possible formation of a side-on peroxo-unit on Co ${ }^{\text {III }}$ metal center (geminal 1,1-intermediate) was concluded following lack of activity of its bpy (2.2'-bipyridine) analogue, where such a conformation is impossible (Fig. 1b). The mechanism suggests that after $\mathrm{OH}^{-}$-promoted hydrolysis of Co-OAc site, formation of the $\mathrm{Co}(\mathrm{OH})_{2}$ intermediates occurs. Then, these 1,1-(hem)-dihydro species undergo oxidation by $(1)^{+}$, followed by $\mathrm{O}_{2}$ release. Several assumptions about the architecture of $\left[\mathrm{CO}_{4} \mathrm{O}_{4}\right]^{\mathrm{n+}}$ cluster bearing highly-oxidized $\mathrm{Co}=0$ species during WOR have been made (Fig. $1 \mathrm{c}$ ) but such species so far escaped detection due to their high reactivity. ${ }^{17,21,23}$ These mechanisms also implied participation of the neighboring Co-Co di-m-oxo moieties in high oxidation states (presumably $\mathrm{Co}^{\mathrm{IV}}=0$ ) during formation of peroxo- species and $\mathrm{O}_{2}$ release (Fig. 1C). Generally, formation of the high-valent metal oxo species is considered a key factor in catalyst activation for oxidation reactions, including WOR but detecting such species remains highly challanging. ${ }^{15,25,26,27,28}$ The peroxo-intermediates of Co and other transition metal oxides participating in WOR were detected using mostly different IR spectroscopic techniques. ${ }^{29}$ Besides the $\mathrm{Co}^{\mathrm{IV}} / \mathrm{Co}^{\mathrm{IV}}$ formation ${ }^{21}$ the possibilities of $\mathrm{Co}^{\mathrm{III}} / \mathrm{Co}^{\mathrm{V}}$ and cofacial hydroxo-oxospecies $\mathrm{Co}^{\mathrm{III}}(\mathrm{OH}) / \mathrm{Co}^{\mathrm{IV}}$ have been considered. ${ }^{21,23} \mathrm{~A}$ similar conformational motif of the edge sites was proposed for the electrocatalytic intermediates of the Co oxides and Co-Pi catalytic films. ${ }^{30,31,32}$

Although formation of $\mathrm{Co}^{\mathrm{IV}}=0$ species as a key intermediate was hypothesized in majority of mechanistic schemes (Fig. 1C) these oxo species have never been observed. Here, we present in situ X-ray absorption spectroscopy (XAS and EXAFS) detection of the $\mathrm{Co}^{\mathrm{IV}}=0$ fragment, supported by EPR and DFT analysis to uncover structure of the reactive intermediates in WOR catalyzed by (1). $\mathrm{Co}=0$ species are extremely elusive, highlighting the concept of the "Oxo wall" - an empirical observation of scarcity of $M=0$ ( $M$ is a transition metal) complexes beyond Group 8 of the periodic table. These species formation has been reported only in exceptional cases, mostly in pyrolytic transformations of Co-based complexes, and none during the WOR. ${ }^{21,25,26,27}$ Our direct observation confirms the generation of the $\mathrm{Co}^{\mathrm{IV}}=0$ intermediate in WOR promoted by $\mathrm{Co}_{4} \mathrm{O}_{4}$ cubane catalysts; subsequent DFT and EPR analysis highlights its ability to directly activate water via water nucleophilic attack (WNA). Comparison of the $\left[\mathrm{CO}_{4} \mathrm{O}_{4}\right]^{\mathrm{n}+}$ unit and the OEC of the PS II during WOR is also discussed.

\section{Results And Discussion}

1. In situ X-ray absorption spectroscopy. In this study we determined the presence of $\mathrm{Co}^{\mathrm{IV}}=0$ intermediate state using in situ XANES and EXAFS of electrochemical WOR of (1) at $1.4 \mathrm{~V} \mathrm{vs.} \mathrm{Ag/AgCl} \mathrm{potential} \mathrm{in} \mathrm{a}$ basic water solution ( $\mathrm{pH}=12$ ) for prolonged time (8 hours) (Fig. 2a, b, Table S1). XAS measurements were performed for initial (1), in situ bulk electrolysis (BE) of (1) at $\mathrm{pH}=12$, and (1) oxidized with cerium (IV) ammonium nitrate (Ce $\mathrm{IV}^{\mathrm{IV}}$ ) at $\mathrm{pH}=1$ (measured at 20K) (Fig. 2a, b). Due to high activity of this catalyst, $\mathrm{pH}$ of the electrochemical solution of (1) during the bulk electrolysis shifted towards increasing acidity; $\mathrm{pH}$ monitoring and basification occurred prior to each X-ray scan, as necessary. Formation of Co species in high oxidation states is reflected in the shift to the higher energy and shape change of the Co K-edge 
(Fig. 2a). At $\mathrm{pH}=1, \mathrm{XAS}$ of the (1) oxidized with 20 equiv of $\mathrm{Ce}^{\mathrm{IV}}$ also revealed K-edge shift to the higher energy (Fig. S1).

Compound (1) contains four Co $\mathrm{O}^{\mathrm{III}}$ ions, while (1) ${ }^{+}$has a single $\mathrm{Co}^{\mathrm{IV}}$. According to DFT calculations, further oxidation of $(1)^{+}$to the $\left[\mathrm{Co}_{2}{ }_{2} \mathrm{Co}_{2}{ }_{2} \mathrm{O}_{4}\right]^{2+}$ is possible (Tables S2, S3) in non-protic solvents. Co K-edge XANES measured during $\mathrm{BE}$ of (1) in water at $\mathrm{pH}=12$ (Fig. 2a) also reflects a formation of the [Co ${ }_{2}{ }_{2} \mathrm{Co}_{2 \mathrm{~V}}$ ] intermediate as reported earlier for electrolysis in $\mathrm{CH}_{3} \mathrm{CN}(\sim 1 \mathrm{eV}$ K-edge shift compared to solution before the BE) ${ }^{21}$ In addition, the top of the edge shape becomes pointier (Fig. 2a). This change indicates a potential geometric change in the cluster and change in the form of the cluster frontier's orbitals. EPR analysis of the samples quickly frozen from the in situ cell during prolonged BE under applied potential indicates mostly EPR silent species, agreeing with [Co $\mathrm{CO}_{2} \mathrm{Co}_{2}{ }_{2}$ ] oxidation state assignment (Fig. 3a, b).

EXAFS analysis indicates considerable changes in the structure of (1) at $\mathrm{pH}=12$ and the applied potential (Fig. 2b). EXAFS fits of the initial (1) and (1) ${ }^{+}$formed by $\mathrm{Ce}^{\mathrm{IV}}$ oxidation agree with known structures of these species (Table S4, Fig. S2). In situ experiment at $\mathrm{pH}=12$ was conducted at two different beamtimes, ensuring EXAFS reproducibility (Table S1). First coordination sphere of Co is comprised of oxygens as $\mathrm{m}^{3}$-oxo bridges, expected Co-0 a $\sim 1.85 \AA$, and single nitrogen ligand from pyridine with Co- $\mathrm{N}$ at $\sim 1.90 \AA$. However, to achieve satisfactory EXAFS fits of the in situ data, addition of short 1.65-1.70 $\AA$ Co-O vector is required (Table S1). This distance agrees well with DFT model of $\left[\mathrm{Co}_{2}{ }_{2}{ }_{2} \mathrm{O}_{4} \mathrm{Co}{ }^{\mathrm{IV}}=\mathrm{O} / \mathrm{Co}^{\mathrm{IV}}\left(\mathrm{CH}_{3} \mathrm{CO}_{2}\right)_{\mathrm{mono}}\right]^{\mathrm{O}}$ (Table 1, S5, Fig. 1d) and is similar to previously-reported $\mathrm{Co}=0$ bond length of $1.72 \AA .{ }^{27}$ For Co-0 at $~ 1.67$ $\AA$, both $\mathrm{N}=0.25$ and $\mathrm{N}=0.5$ vectors give similar fit results. Thus, EXAFS fits cannot distinguish whether the intermediate has one or two $\mathrm{Co}^{\mathrm{IV}}=\mathrm{O}$ units, while higher number of units is unlikely. Our DFT analysis (below) shows that one $\mathrm{Co}^{\mathrm{IV}}=\mathrm{O}$ fragment per $\left[\mathrm{Co}_{4} \mathrm{O}_{5}\right]^{\mathrm{n}+}$ may enable $\mathrm{O}-\mathrm{O}$ bond formation. DFT of [Co $\left.{ }^{I I I}{ }_{2} \mathrm{O}_{4} \mathrm{Co}^{\mathrm{IV}}=\mathrm{O} / \mathrm{Co}^{\mathrm{IV}}\left(\mathrm{CH}_{3} \mathrm{CO}_{2}\right)_{\text {mono }}\right]^{0}$ model also predicts two groups of Co-Co distances: one shorter ( 2.73 $\AA$ ) and one longer ( 2.86-2.91 $\mathrm{A}$ ). EXAFS fits improve if Co-Co vector is split into two shells (Table S1).

2. In situ EPR. Oxidation of ( 1 ) by one electron results in well-known paramagnetic $(S=1 / 2)$ cubium signal (1).$+{ }^{+14}$ This signal can be produced by oxidation with $\mathrm{Ce}^{\mathrm{IV}}$ at acidic $\mathrm{pH}$ or by bulk electrolysis at neutral $\mathrm{pH} 7$ where the catalyst is inactive (Fig. S6). EPR samples from bulk electrolysis in $\mathrm{pH}=12$ solution at 1.4 $\mathrm{V}$ vs. $\mathrm{Ag} / \mathrm{AgCl}$ electrode were quickly frozen and analyzed by X-band EPR at $20 \mathrm{~K}$ (Fig. 3a, b). Such samples are largely EPR silent, except for the background due to frozen oxygen evolved under these BE conditions. Loss of EPR signal is consistent with further sample oxidation to (1) ${ }^{2+}$ state, which can have $\left[\mathrm{Co}_{2}{ }_{2} \mathrm{O}_{4} \mathrm{Co}^{\mathrm{IV}}=\mathrm{O} / \mathrm{Co}^{\mathrm{IV}}\left(\mathrm{CH}_{3} \mathrm{CO}_{2}\right)_{\text {mono }}\right]^{0}$ form, as discussed below based on XAS analysis and DFT. Traces of cubium (1) ${ }^{+}$signal are detected upon sample melting (data not shown). New, short-lived $S=1 / 2$ signal is detected when spectra are closely analyzed (Fig. 3, b). The signal peaks at $g \sim 2.08$ and has $\mathrm{g}_{\mathrm{zz}}$ component centered around g 1.80. Hyperfine splitting $\sim 50-60 \mathrm{G}$ is noticeable around $\mathrm{g}_{\mathrm{zz}}$ component and to the left of the $\mathrm{g} \sim 2.08$ peak. It is assigned to the ${ }^{59} \mathrm{Co} \mathrm{I}=7 / 2 \mathrm{hfs}$. The g-tensor values near $\mathrm{g} 2$ 
indicate a significant electron localization on the ligand. Low g-tensor values were previously reported for Co ${ }^{\mathrm{III}}-\mathrm{O}_{2}{ }^{-}$superoxo com-

Table 1. DFT analysis of $\mathrm{O}-\mathrm{O}$ bond formation by $\mathrm{Co}^{\mathrm{III}}{ }_{2} \mathrm{Co}^{\mathrm{IV}}{ }_{2}$ state of the $\mathrm{Co}_{4} \mathrm{O}_{4}$ - cubane

Reactions of O-O bond formation

$\mathrm{DG}, \mathrm{eV}$

BP86

${ }^{\mathrm{T}} \mathrm{Co}_{2}{ }_{2} \mathrm{O}_{4} \mathrm{Co}^{\mathrm{IV}}=\mathrm{O} / \mathrm{Co}^{\mathrm{IV}}\left(\mathrm{CH}_{3} \mathrm{CO}_{2}\right)_{\text {mono }}+\mathrm{H}_{2} \mathrm{O}={ }^{\mathrm{S}} \mathrm{Co}_{2}{ }_{2} \mathrm{O}_{4} \mathrm{Co}^{\text {III- }}$

$\mathrm{OOH} / \mathrm{Co}^{\text {III }}\left(\mathrm{CH}_{3} \mathrm{CO}_{2} \mathrm{H}\right)_{\text {mono }}$

${ }^{\mathrm{T}} \mathrm{Co}_{2}{ }_{2} \mathrm{O}_{4} \mathrm{Co}^{\mathrm{IV}}=\mathrm{O} / \mathrm{Co}^{\mathrm{IV}}\left(\mathrm{CH}_{3} \mathrm{CO}_{2}\right)_{\mathrm{mono}} / \mathrm{H}_{2} \mathrm{O}={ }^{\mathrm{S}} \mathrm{Co}^{\mathrm{III}}{ }_{2} \mathrm{O}_{4} \mathrm{Co}^{\mathrm{III}}-$

$\mathrm{OOH} / \mathrm{Co}^{\text {III }}\left(\mathrm{CH}_{3} \mathrm{CO}_{2} \mathrm{H}\right)_{\text {mono }}$

${ }^{\mathrm{T}} \mathrm{Co}_{2}{ }_{2} \mathrm{O}_{4} \mathrm{Co}^{\mathrm{IV}}=\mathrm{O} / \mathrm{Co}^{\mathrm{IV}}\left(\mathrm{CH}_{3} \mathrm{CO}_{2}\right)_{\text {mono }}={ }^{\mathrm{S}} \mathrm{Co}_{3}{ }_{3} \mathrm{O}_{4} \mathrm{Co}^{\mathrm{III}}\left(\mathrm{OOC}(\mathrm{O}) \mathrm{CH}_{3}\right)_{\text {bridging }}$

BP86 with $15 \%$ Hartree Fock

${ }^{\mathrm{T}} \mathrm{Co}_{2}{ }_{2} \mathrm{O}_{4} \mathrm{Co}^{\mathrm{IV}}=\mathrm{O} / \mathrm{Co}^{\mathrm{IV}}\left(\mathrm{CH}_{3} \mathrm{CO}_{2}\right)_{\text {mono }}+\mathrm{H}_{2} \mathrm{O}={ }^{\mathrm{S}} \mathrm{Co}_{2}{ }_{2} \mathrm{O}_{4} \mathrm{Co}^{\text {III- }}$

$\mathrm{OOH} / \mathrm{Co}^{\mathrm{III}}\left(\mathrm{CH}_{3} \mathrm{CO}_{2} \mathrm{H}\right)_{\text {mono }}$

${ }^{\mathrm{T}} \mathrm{Co}_{2}{ }_{2} \mathrm{O}_{4} \mathrm{Co}^{\mathrm{IV}}=\mathrm{O} / \mathrm{Co}^{\mathrm{IV}}\left(\mathrm{CH}_{3} \mathrm{CO}_{2}\right)_{\mathrm{mono}} / \mathrm{H}_{2} \mathrm{O}={ }^{\mathrm{S}} \mathrm{Co}_{2}{ }_{2}{ }_{2} \mathrm{O}_{4} \mathrm{Co}^{\text {III- }}$

$\mathrm{OOH} / \mathrm{Co}^{\text {III }}\left(\mathrm{CH}_{3} \mathrm{CO}_{2} \mathrm{H}\right)_{\text {mono }}$

Additional oxidation reactions

Redox potential, E, $\mathrm{eV}$

${ }^{\mathrm{T}} \mathrm{Co}_{2}{ }_{2} \mathrm{O}_{4} \mathrm{Co}^{\mathrm{IV}}=\mathrm{O} / \mathrm{Co}^{\mathrm{IV}}\left(\mathrm{CH}_{3} \mathrm{CO}_{2}\right)_{\mathrm{mono}}={ }^{\mathrm{D}} \mathrm{Co}^{\mathrm{III}} \mathrm{O}_{4} \mathrm{Co}^{\mathrm{IV}}=\mathrm{O} / \mathrm{Co}^{\mathrm{IV}}, \mathrm{Co}^{\mathrm{IV}}\left(\mathrm{CH}_{3} \mathrm{CO}_{2}\right)_{\mathrm{mono}}+\quad+0.86$ $\mathrm{e}^{-}$

${ }^{\mathrm{S}} \mathrm{Co}_{2}{ }_{2} \mathrm{O}_{4} \mathrm{Co}{ }^{\prime \prime \prime}-\mathrm{OOH} / \mathrm{Co}^{\prime \prime \prime}\left(\mathrm{CH}_{3} \mathrm{CO}_{2} \mathrm{H}\right)_{\text {mono }}={ }^{\mathrm{D}} \mathrm{Co}^{\prime \prime \prime}{ }_{2} \mathrm{O}_{4} \mathrm{Co}^{\mathrm{IV}}$ -

$+0.12$

$\mathrm{OOH} / \mathrm{Co}^{\text {III }}\left(\mathrm{CH}_{3} \mathrm{CO}_{2} \mathrm{H}\right)_{\text {mono }}+\mathrm{e}^{-}$ 
plexes. ${ }^{33,34,35}$ Below we compare DFT computed ${ }^{59} \mathrm{Co}$ hfs and conclude that an assignment of this new signal is possible as $\mathrm{Co}^{\mathrm{IV}}-\mathrm{OOH}$ terminal peroxo species.

3. DFT analysis. Multiple potential mechanisms for $\mathrm{O}-\mathrm{O}$ formation by $\left[\mathrm{Co}_{4} \mathrm{O}_{4}\right]^{\text {n+ }}$ cubane have been discussed (Figure 1b, c). 13, 14, 15, 16, 17, 21, 22, 24 The experimental consensus that bridging oxygens do not exchange under catalytic conditions suggests that $0-0$ bond formation involving bridging oxygens should not be considered. It is experimentally established that $\mathrm{Co}_{2}{ }_{2} \mathrm{Co}^{\mathrm{IV}}{ }_{2}$ is a catalytically competent state.

One observation that $\left[\mathrm{Co}_{4} \mathrm{O}_{4}(\mathrm{bpy})_{4} \mathrm{Ac}_{2}\right]^{2+}$ is not an active catalyst called for a specific mechanism with side-on peroxide formation from $\mathrm{Co}(\mathrm{OH})_{2}$ corner (Figure $\left.1 \mathrm{~b}\right) .{ }^{14}$ The redox potential for $(1)$ to form $\mathrm{Co}_{2}{ }_{2} \mathrm{Co}_{2}{ }_{2}$ in acetonitrile solvent ${ }^{21}$ is in Table S2. Cyclic voltammogram data for (1) in acetonitrile has confirmed the earlier result ${ }^{21}$ (Figure S3), while in the same electrochemical window the bpy analog reversibly oxidizes at $\sim+0.71 \mathrm{~V} .{ }^{6,36}$ However, no second redox couple was observed. Hence, oxidation of the bpy derivative requires greater energy input, likely due to its positive charge. DFT calculations confirm this effect (Table S3). Note that protic solvents are known to form hydrogen bonds to the cubane $\mu_{3}$-oxos, reducing donation to cobalt and raising the potentials in aqueous solution. ${ }^{17}$ This effect causes (1) and the bpy analog to reach the $\mathrm{Co}_{3}{ }_{3} \mathrm{Co}^{\mathrm{IV}}$ level at identical potential in water. Nonetheless, the $\mathrm{Co}_{2}{ }_{2} \mathrm{Co}^{\mathrm{IV}}{ }_{2}$ level was observed for (1) and remain undetected for the bpy analog, potentially explaining lack of its catalytic activity.

The $\left[\mathrm{Co}^{\mathrm{III}}{ }_{2} \mathrm{Co}_{2 \mathrm{~V}}\right]^{2+}$ cubane can be in a triplet $(\mathrm{S}=1)$ or a singlet state $(\mathrm{S}=0)$. Both these states are energetically equal. ${ }^{21}$ We interpret in situ XANES results as an observation of $\mathrm{Co}_{2}{ }_{2} \mathrm{Co}^{\mathrm{IV}}{ }_{2}$ intermediate, agreeing with the earlier studies. ${ }^{21}$ EXAFS data indicate that at $\mathrm{pH}=12$ the intermediate contains at least one $\mathrm{Co}^{\mathrm{IV}}=0$ group. The minimally modified structure where this group can be achieved is $\left[\mathrm{Co}_{2}{ }_{2} \mathrm{O}_{4} \mathrm{Co}^{\mathrm{IV}}=\mathrm{O} / \mathrm{Co}^{\mathrm{IV}}\left(\mathrm{CH}_{3} \mathrm{CO}_{2}\right)_{\text {mono }}\right]^{0}$ where the single bridging acetate becomes a terminal ligand (Figure $1 \mathrm{~d}$ ). For this structure, the triplet state is $\sim 0.7 \mathrm{eV}$ lower than the singlet (Table S5). DFT-computed $\mathrm{Co}^{\mathrm{IV}}=0$ in this intermediate $(\sim 1.675 \AA)$ matches well the Co-0 distance $(\sim 1.67 \AA)$ detected in EXAFS (Table S1). Co-Co distances that are separated into two groups, the shorter $(\sim 2.73 \AA)$ and the longer $(\sim 2.85 \AA)$, also match the DFT model (Table S1).

Recent time-resolved rapid-scan IR observation of photo-oxidized cubane at $\mathrm{pH}=12.3$ indicates no free acetate at reaction conditions, suggesting that all acetates remain at least as the terminal ligands to the cubane. ${ }^{29}$ However, this observation contradicts the paper's following interpretations: assigning $\sim 833 \mathrm{~cm}^{-}$ ${ }^{1}$ band to Co-OO-Co peroxo species. Thus, we explored [ $\left.\mathrm{Co}_{2}{ }_{2} \mathrm{O}_{4} \mathrm{Co}^{\mathrm{IV}}=\mathrm{O} / \mathrm{Co}^{\mathrm{IV}}\left(\mathrm{CH}_{3} \mathrm{CO}_{2}\right)_{\text {mono }}\right]^{0}$ reaction with water via WNA mechanism which has negative $(-0.27 \mathrm{eV}) \mathrm{DG}$ in the calculations done with $15 \%$ of Hartree Fock exchange (Table 1, Fig. 1d). Multiple 
Table 2. DFT computed key spectroscopic characteristics of the reactive intermediates in BE of (1) in water solution at $\mathrm{pH}=12$ at $1.4 \mathrm{~V}$ vs $\mathrm{Ag} / \mathrm{AgCl}$ applied potential. 
Intermediate/

${ }^{59} \mathrm{Co}$ hfs in gauss for $\mathrm{S}=1 / 2$ species

${ }^{\mathrm{T}} \mathrm{Co}_{2}{ }_{2} \mathrm{O}_{4} \mathrm{Co}^{\mathrm{IV}}=\mathrm{O} / \mathrm{Co}^{\mathrm{IV}}\left(\mathrm{CH}_{3} \mathrm{CO}_{2}\right)_{\text {mono }}$

$\mathrm{Co}=0: 744 \mathrm{~cm}^{-1}$ $\mathrm{Co}={ }^{18} \mathrm{O}: 713 \mathrm{~cm}^{-1}$

$\left(911 \mathrm{~cm}^{-1}\right)$

(1.61 angstroms)

${ }^{\mathrm{S}} \mathrm{Co}_{2}{ }_{2} \mathrm{O}_{4} \mathrm{Co}{ }^{\text {III- }}-\mathrm{OOH} / \mathrm{Co}^{\text {III }}\left(\mathrm{CH}_{3} \mathrm{CO}_{2} \mathrm{H}\right)_{\text {mono }}$

-O-OH: $762 \mathrm{~cm}^{-1}$

$\left(985 \mathrm{~cm}^{-1}\right)$

(Co-0: 1.86A)

(0-0: 1.41A)

$-0-\mathrm{OH}: 821 \mathrm{~cm}^{-1}$

${ }^{\mathrm{S}} \mathrm{Co}_{2}{ }_{2} \mathrm{O}_{4} \mathrm{Co}{ }^{\text {III- }} \mathrm{OOH} / \mathrm{Co}^{\text {III }}\left(\mathrm{CH}_{3} \mathrm{CO}_{2}\right)_{\text {mono }}$
-O-OD: $761 \mathrm{~cm}^{-1}$

-180-OH: $738 \mathrm{~cm}^{-1}$

$-{ }^{18} \mathrm{O}-{ }^{18} \mathrm{OH}: 718 \mathrm{~cm}^{-1}$

-0-18 $\mathrm{OH}: 742 \mathrm{~cm}^{-1}$

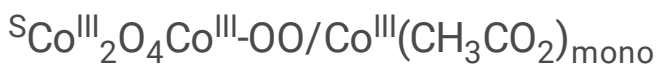

$\mathrm{Co}_{2}{ }_{2} \mathrm{O}_{4} \mathrm{Co}^{\mathrm{IV}}-\mathrm{OOH} / \mathrm{Co}^{\text {III }}\left(\mathrm{CH}_{3} \mathrm{CO}_{2} \mathrm{H}\right)_{\text {mono }}$

${ }^{59}$ Co hfs: $A_{x x}=34 ; A_{y y}=58 ; A_{z z}=78$

-O-OH: $932 \mathrm{~cm}^{-1}$

$-\mathrm{O}-\mathrm{OH}: 807 \mathrm{~cm}^{-1}$

$-0-\mathrm{OH}: 875 \mathrm{~cm}^{-1}$

$\mathrm{Co}_{2}{ }_{2} \mathrm{O}_{4} \mathrm{Co}^{\mathrm{IV}}-\mathrm{OOH} / \mathrm{Co}^{\text {III }}\left(\mathrm{CH}_{3} \mathrm{CO}_{2}\right)_{\text {mono }}$

${ }^{59}$ Co hfs: $A_{x x}=30 ; A_{y y}=52 ; A_{z z}=75$
-O-OD: $809 \mathrm{~cm}^{-1}$

-180-OH: $782 \mathrm{~cm}^{-1}$

$-{ }^{18} \mathrm{O}-{ }^{18} \mathrm{OH}: 762 \mathrm{~cm}^{-1}$

$-0-{ }^{18} \mathrm{OH}: 786 \mathrm{~cm}^{-1}$

-O-OD: $873 \mathrm{~cm}^{-1}$

$-18 \mathrm{O}-\mathrm{OH}: 849 \mathrm{~cm}^{-1}$

$-{ }^{18} \mathrm{O}-{ }^{18} \mathrm{OH}: 826 \mathrm{~cm}^{-1}$

$-0-{ }^{18} \mathrm{OH}: 852 \mathrm{~cm}^{-1}$

$\mathrm{Co}_{2}{ }_{2} \mathrm{O}_{4} \mathrm{Co}^{\mathrm{IV}}-\mathrm{OO} / \mathrm{Co}^{\mathrm{III}}\left(\mathrm{CH}_{3} \mathrm{CO}_{2}\right)_{\text {mono }}$

-O-OH: $1090 \mathrm{~cm}^{-1}$

${ }^{59}$ Co hfs: $A_{x x}=16 ; A_{y y}=15 ; A_{z z}=22$

${ }^{\mathrm{S}} \mathrm{Co}_{3}{ }_{3} \mathrm{O}_{4} \mathrm{Co}^{\text {III }}\left(\mathrm{OOC}(\mathrm{O}) \mathrm{CH}_{3}\right)_{\text {bridging }}$

Co-O-O-C

$725 \mathrm{~cm}^{-1}$

$\mathrm{Co}_{2}{ }_{2} \mathrm{O}_{4} \mathrm{Co}^{\prime \prime \prime}-\mathrm{OO}-\mathrm{Co}^{\prime \prime \prime}$

$\mathrm{Co}_{2}{ }_{2} \mathrm{O}_{4} \mathrm{Co}^{\mathrm{IV}}-\mathrm{OO}-\mathrm{Co}^{\prime \prime \prime}$
0-0 $718 \mathrm{~cm}^{-1}$

0-0 $905 \mathrm{~cm}^{-1}$
$\mathrm{Co}^{18} \mathrm{O}-\mathrm{O}-\mathrm{C}$

$720 \mathrm{~cm}^{-1}$ 


$$
\begin{aligned}
& { }^{59} \text { Co hfs: } A_{x x}=14 ; A_{y y}=11 ; A_{z z}=23 \\
& { }^{59} \text { Co hfs: } A_{x x}=13 ; A_{y y}=11 ; A_{z z}=23
\end{aligned}
$$

* Isotope shifts were computed for most promising intermediates.

research groups noted that inclusion of variable \% of Hartree Fock exchange stabilizes the peroxide species in PS II OEC. $37,38,39$ In the $0-0$ bond formation the terminal acetate acts as a proton acceptor group. A barrier of $\sim+0.9 \mathrm{eV}$ is estimated for the computed WNA process (Movie S1, see Supporting Information for details, Fig. S7). Additional driving force can be provided by proton removal at $\mathrm{pH}=12$ and oxidation of formed $\mathrm{Co}_{3}{ }_{3} \mathrm{O}_{4} \mathrm{Co} \mathrm{CO}_{-} \mathrm{IIOH}$ to $\mathrm{Co}_{3}{ }_{3} \mathrm{O}_{4} \mathrm{Co}^{\mathrm{IV}}(\mathrm{OOH})$. This should require a moderate potential (Table 1) while shifting an equilibrium towards a peroxo form.

Direct involvement of oxygen-containing ligands such as $\mathrm{N}$-oxides and carboxylates into $\mathrm{O}-\mathrm{O}$ bond formation was proposed for some water oxidation catalysts. ${ }^{40,41}$ Currently, experimental confirmation of the direct carboxylate ligand involvement in $\mathrm{O}-\mathrm{O}$ bond formation is lacking. Nevertheless, for complete analysis of all possible pathways, ${ }^{\mathrm{S}}\left[\mathrm{Co}^{\mathrm{III}}{ }_{3} \mathrm{O}_{4} \mathrm{Co}{ }^{\mathrm{III}}\left(\mathrm{OOC}(\mathrm{O}) \mathrm{CH}_{3}\right)_{\text {bridging }}\right]^{0}$ product of $\mathrm{O}-\mathrm{O}$ bond formation was computed (Table 1). Energetically, this pathway is similar in energy to WNA but was not further investigated pending an experimental evidence.

DFT-computed spectroscopic properties of proposed intermediates are summarized in Table 2. The $\mathrm{O}-\mathrm{OH}$ vibration in ${ }^{\mathrm{S}}\left[\mathrm{Co}_{2}{ }_{2} \mathrm{O}_{4} \mathrm{Co}{ }^{\text {III-}}-\mathrm{OOH} / \mathrm{Co}^{\text {III }}\left(\mathrm{CH}_{3} \mathrm{CO}_{2} \mathrm{H}\right)_{\text {mono }}\right]^{0}$ peroxide is $\sim 762 \mathrm{~cm}^{-1}$ and is insensitive to $\mathrm{O}-\mathrm{OH}$ to $\mathrm{O}-\mathrm{OD}$ exchange (Table 2). Thus, this type of end-on peroxide also agrees with reported $\mathrm{FT}-\mathrm{IR}^{29} \cdot \mathrm{O}-\mathrm{OH}$ vibration $\left(\sim 807 \mathrm{~cm}^{-1}\right)$ of the oxidized [ $\mathrm{Co}_{2}{ }_{2} \mathrm{O}_{4} \mathrm{Co}^{\mathrm{IV}}-\mathrm{OOH} / \mathrm{Co}^{\mathrm{III}}\left(\mathrm{CH}_{3} \mathrm{CO}_{2} \mathrm{H}\right)_{\text {mono }}{ }^{+}$form is highly plausible under applied potential and better agrees with the FT-IR experiment. Deprotonation of carboxylate ligand, plausible at $\mathrm{pH}=12$ (Table S8), shifts computed 0-O vibration further to $\sim 875 \mathrm{~cm}^{-1}$ (Table 2). Both $\left[\mathrm{Co}_{2}{ }_{2} \mathrm{O}_{4} \mathrm{Co}^{\mathrm{IV}}-\mathrm{OOH} / \mathrm{Co}^{\mathrm{III}}\left(\mathrm{CH}_{3} \mathrm{CO}_{2} \mathrm{H}\right)_{\text {mono }}\right]^{0}$ and $\left[\mathrm{Co}_{2}{ }_{2} \mathrm{O}_{4} \mathrm{Co}^{\mathrm{IV}}-\mathrm{OOH} / \mathrm{Co}^{\mathrm{III}}\left(\mathrm{CH}_{3} \mathrm{CO}_{2}\right)_{\text {mono }}\right]^{+}$result in O-O vibrational frequencies very close (taking into account $\sim 50 \mathrm{~cm}^{-1}$ uncertainty of calculations) to experimentally reported $\sim 833 \mathrm{~cm}^{-1}$ frequency ${ }^{29}$.

DFT-computed ${ }^{59} \mathrm{Co}$ hyperfine splitting of both $\left[\mathrm{Co}^{\prime \prime \prime I}{ }_{2} \mathrm{O}_{4} \mathrm{Co}^{\mathrm{IV}}-\mathrm{OOH} / \mathrm{Co}^{\mathrm{III}}\left(\mathrm{CH}_{3} \mathrm{CO}_{2} \mathrm{H}\right)_{\text {mono }}\right]^{+}$and [Co $\left.{ }_{2}{ }_{2} \mathrm{O}_{4} \mathrm{Co}^{\mathrm{IV}}-\mathrm{OOH} / \mathrm{Co}^{\text {III }}\left(\mathrm{CH}_{3} \mathrm{CO}_{2}\right)_{\text {mono }}\right]^{0}$ species is in agreement with EPR results (Table 2). Considering pH and applied potential, we conclude that $\left[\mathrm{Co}_{2}{ }_{2} \mathrm{O}_{4} \mathrm{Co}^{\mathrm{IV}}-\mathrm{OOH} / \mathrm{Co}^{\mathrm{III}}\left(\mathrm{CH}_{3} \mathrm{CO}_{2}\right)_{\text {mono }}\right]^{0}$ is likely a peroxo intermediate with spectroscopic properties matching FT-IR and EPR. DFT predicts weak driving force for its deprotonation forming [Co $\left.{ }^{\prime \prime \prime}{ }_{2} \mathrm{O}_{4} \mathrm{Co}^{\mathrm{IV}}-\mathrm{OO} / \mathrm{Co}^{\mathrm{III}}\left(\mathrm{CH}_{3} \mathrm{CO}_{2}\right)_{\mathrm{mono}}\right]^{-}$(Table S8). [Co ${ }_{2} \mathrm{O}_{4} \mathrm{Co}^{\mathrm{IV}}$ $\left.00 / \mathrm{Co}^{\mathrm{II}}\left(\mathrm{CH}_{3} \mathrm{CO}_{2}\right)_{\mathrm{mono}}\right]^{-}$is predicted to have smaller ${ }^{59} \mathrm{Co}$ hfs on the order of $15-22 \mathrm{G}$ (Table 2) due to 
larger spin density localization on - 00 superoxo fragment. This is an end-on peroxo intermediate while the attempts to produce side-on peroxide lead towards end-on state.

We computed bridging peroxide ( $\mathrm{Co}_{2}{ }_{2} \mathrm{O}_{4} \mathrm{Co}^{\mathrm{III}}-\mathrm{OO}-\mathrm{Co}^{\mathrm{III}}$ ) that was proposed to explain FT-IR results ${ }^{29}$ but obtained $\sim 718 \mathrm{~cm}^{-1}$. This $0-0$ bond frequency significantly deviates from the experimental $\sim 833 \mathrm{~cm}^{-1}$ value. The $\mathrm{O}-\mathrm{O}$ vibration in oxidized bridging peroxo- intermediate $\mathrm{Co}_{2}{ }_{2} \mathrm{O}_{4} \mathrm{Co}^{\mathrm{IV}}-\mathrm{OO}-\mathrm{Co}{ }^{\text {III }}$ was computed to be $~ 905 \mathrm{~cm}^{-1}$. Generation of $\mathrm{Co}_{2}{ }_{2} \mathrm{O}_{4} \mathrm{Co}^{\mathrm{IV}}=\mathrm{O} / \mathrm{Co}^{\mathrm{IV}}=\mathrm{O}$ (Fig. 1c) and its precursor of $\mathrm{Co}_{2}{ }_{2} \mathrm{O}_{4} \mathrm{Co}^{\text {III-OO- }-\mathrm{Co}} \mathrm{III}^{\mathrm{III}}$ bridging peroxide, carries additional $\sim+0.6 \mathrm{eV}$ per removed proton penalty when compared with the generation of $\mathrm{Co}_{2}{ }_{2} \mathrm{O}_{4} \mathrm{Co}^{\mathrm{IV}}=\mathrm{O} / \mathrm{Co}^{\mathrm{IV}}\left(\mathrm{CH}_{3} \mathrm{CO}_{2}\right)_{\mathrm{mono}}$.

(Table 1). We did not computationally investigate pathway in Fig. 1b since it requires de-coordination of two ace-tate ligands from the same Co center. We suggest that statistically it is less probable than decoordination of just one acetate ligand.

A strong motivation to study the $\mathrm{Co}_{4} \mathrm{O}_{4}$ cubane was its resemblance to the $\mathrm{CaMn}_{4} \mathrm{O}_{5}$ cluster of PS II photosynthetic enzyme. ${ }^{14,42}$ In 2015 , we proposed $\mathrm{Mn}^{\mathrm{IV}}=0$ as an intermediate of the $\mathrm{S}_{3}$-state of the OEC able to satisfy spectroscopic properties and be positioned to form 0-0 bond early in the $\mathrm{S}_{3}$ to $\mathrm{S}_{0}$ transition (Fig. 4a). ${ }^{37,43,44}$ Time-resolved XRD analysis of the $S_{3}$ state ${ }^{45,46,47}$ resulted in data that might be interpreted as a formation of at least three possible structures: $\mathrm{Mn}^{\mathrm{IV}}-\mathrm{OH}, \mathrm{Mn}-\mathrm{OO}-\mathrm{Mn}, \mathrm{or} \mathrm{Mn}^{\mathrm{IV}}=0$, with the last one favored in the most recent study ${ }^{45}$. Interestingly, $\left[\mathrm{Co}_{2}{ }_{2} \mathrm{O}_{4} \mathrm{Co}^{\mathrm{IV}}=\mathrm{O} / \mathrm{Co}^{\mathrm{IV}}\left(\mathrm{CH}_{3} \mathrm{CO}_{2}\right)_{\text {mono }}\right]^{0}$ displays strong radicaloid character for the oxygen in the $\mathrm{Co}^{\mathrm{IV}}=0$ group (see spin density, Fig. $1 \mathrm{~d}$ ). Similar radicaloid character of the $\mathrm{Ru}^{\mathrm{V}}=\mathrm{O}$ fragment oxygen was established via direct spin density mapping by EPR for water oxidation intermediate in the "blue dimer" catalyst. ${ }^{48}$ In the PS II, the 0-0 bond was proposed to form via radical coupling between the oxygens in $\mathrm{Mn}^{\mathrm{IV}}=0$ and bridging $\mathrm{Mn}-\mathrm{O}-\mathrm{Mn} .{ }^{37,49}$ Mechanism observed for the $\left[\mathrm{Co}_{2}{ }_{2} \mathrm{O}_{4} \mathrm{Co}^{\mathrm{IV}}=\mathrm{O} / \mathrm{Co}^{\mathrm{IV}}\left(\mathrm{CH}_{3} \mathrm{CO}_{2}\right)_{\text {mono }}\right]^{0}$ with involvement of the carboxylate and bridging oxygen as proton acceptors in the $\mathrm{O}-\mathrm{O}$ bond formation (Fig. $1 \mathrm{~d}$ ), prompted analysis of similar configurations for the OEC (Fig. 4). The $\mathrm{S}_{3}$ state model allows WNA of the $\mathrm{Ca}^{2+}$-bound $\mathrm{H}_{2} \mathrm{O}$ on the $\mathrm{Mn}^{\mathrm{IV}}=\mathrm{O}$. The closest carboxylate ligand able to accept a proton is $\mathrm{E} 189$, while two oxo bridges, the left $(\sim+0.2 \mathrm{eV})$ and the right one $(\sim+1.5 \mathrm{eV})$, of the $\mathrm{Mn}^{\mathrm{IV}}=0$ fragment may form hydrogen bonds with the peroxides formed (Fig. 4b). Such peroxides are energetically plausible for formation, even at $S_{3}$ state. Note that formation of a peroxide via radical coupling will better agree with the TR-XRD data of the $\mathrm{S}_{3}$ state, as this does not require additional oxygen atoms except already detected in TR-XRD. ${ }^{45,46,47}$ To account for peroxides formed via WNA on the $\mathrm{Mn}^{\mathrm{IV}}=0$, additional oxygen density should be present in the $\mathrm{S}_{3}$ state (Fig. 4a). Thus, such a peroxide can only be possible as a minor configuration. One electron oxidation of the OEC forming the $\mathrm{S}_{4}$ state results in similar energetics with $(\sim+1.8 \mathrm{eV})$ for the left and $(\sim+0.2 \mathrm{eV})$ for the right (Fig. 4b, Table S9). Future detection of electron densities in the $\mathrm{S}_{4}$ state (formed 
$\sim 200-1000 \mathrm{msec}$ in the $S_{3}$ to $S_{0}$ transition) will help to discriminate between radical coupling and WNA mechanisms.

\section{Methods}

Complex (1) was prepared as previously described. ${ }^{14}$ UV-vis spectra were recorded on Varian Cary 300Bio spectrophotometer. Aqueous solutions were prepared using ultrapure (Type 1) water (resistivity 18.2 $\mathrm{M} \Omega \cdot \mathrm{cm}$ at $25^{\circ} \mathrm{C}$ ) from Q-POD unit of Milli-Q integral water purification system (Millipore, Billerica, MA, USA). XAS measurements were made for bulk electrolysis of (1) in water in situ in a basic media at beamline 9 of Argonne National Laboratory using a potentiostat (CHI 627C; $\mathrm{CH}$ Instruments Inc., Austin, TX, USA) and a custom made single-compartment 3-electrode cell with flexible grafoil tape as a working electrode and $4 \mu \mathrm{m}$ polypropylene tape window for XAS. The electrolysis of (1) was performed in $0.1 \mathrm{M}$ sodium sulfate water solution basified with appropriate amount of sodium hydroxide to $\mathrm{pH}=12$. The cell was equipped with grafoil as the working electrode, Pt wire as the counter electrode in an auxiliary chamber and $\mathrm{Ag} / \mathrm{AgCl}$ as the reference electrode at $1.4 \mathrm{~V}$ vs. $\mathrm{Ag} / \mathrm{AgCl}$ applied potential and $0.4 \mu \mathrm{M}$ mylar tape window on the X-ray path. A basicity of the solutions in the cell and auxiliary chamber were measured after each scan and adjusted to $\mathrm{pH}=12$ if necessary. Electrochemical measurements which did not take place at the beamline were performed on a Biologic VSP potentiostat with a typical three electrode cell: Glassy carbon working electrode, Pt wire counter electrode, and $\mathrm{Ag} / \mathrm{AgCl}$ reference. The medium was $0.1 \mathrm{M}$ tetrabutylammonium hexafluorophosphate in acetonitrile, and measurements were performed under an $\mathrm{N}_{2}$ atmosphere. The data are referenced to the experimentally determined ferrocene redox couple.

X-band EPR measurements were conducted at $20 \mathrm{~K}$ temperature with Bruker EMX X-band spectrometer and $\mathrm{CW}$ microwave radiation using ColdEdge- closed cycle cryostat. The EPR samples were prepared by mixing 200 ul of $1 \mathrm{mM}$ of (1) in $0.1 \mathrm{M} \mathrm{HNO}_{3}$ with appropriate amount of $\mathrm{Ce}^{\mathrm{IV}}$ in an EPR tube, followed by freezing in liquid $\mathrm{N}_{2}$ in less than 30 seconds.

All reported measurements were repeated several times to ensure the reproducibility of results.

\section{Conclusions}

Observation of $\mathrm{Co}^{\mathrm{IV}}=\mathrm{O}$ intermediate and its comparison with $\mathrm{CaMn}_{4} \mathrm{O}_{5}$ cluster of PSII during WOR strengthens understanding of the water oxidation mechanisms for both systems. The "oxo-wall" effect may be mitigated in the multi-metal clusters like $\left[\mathrm{Co}_{4} \mathrm{O}_{4} \mathrm{Ac}_{4} \mathrm{Py}_{4}\right]^{0}$. X-ray spectroscopy data and DFT calculations indicate an importance of water nucleophilic attack in electrochemical water oxidation promoted by $\mathrm{Co}_{4} \mathrm{O}_{4}$-cubane. This pathway is similar to WOR catalyzed by group 8 transition metals, forming intermediates in high oxidation states. ${ }^{28,50}$ Formation of $\mathrm{Co}^{\mathrm{V}}$ has not been supported experimentally or with DFT. Thus, 0-0 bond formation likely proceeds through the 
[Co $\left.{ }^{\mathrm{III}}{ }_{2} \mathrm{O}_{4} \mathrm{Co}^{\mathrm{IV}}=\mathrm{O} / \mathrm{Co}^{\mathrm{IV}}\left(\mathrm{CH}_{3} \mathrm{CO}_{2}\right)_{\text {mono }}\right]^{0}$ unit, followed by WNA and peroxo- species formation. These results inform rational design of Co-based WOCs suitable for electrocatalytic water oxidation.

\section{Declarations}

\section{AUTHOR INFORMATION}

Corresponding Author

*ypushkar@purdue.edu

\section{ACKNOWLEDGMENTS}

This research was supported by NSF, CHE-1900476 (Y.P.) and Valparaiso University (P.S.). The use of the Advanced Photon Source, an Office of Science User Facility operated by the U.S. Department of Energy (DOE) Office of Science by Argonne National Laboratory, was supported by the U.S. DOE under Contract DE-AC02-06CH11357. The PNC/XSD (Sector 20) facilities at the Advanced Photon Source and research at these facilities were supported by the U.S. Department of Energy, Basic Energy Science, and the Canadian Light Source. Access to EPR was provided by the Amy Instrumentation Facility, Department of Chemistry, under the supervision of Dr. Michael Everly. We thank Prof G. C. Dismukes from Rutgers University for supply of the sample and helpful discussion and Prof. L. Slipchenko from Purdue University for providing computational resources and helpful discussion.

\section{References}

1. Glenk G, Reichelstein S. Economics of converting renewable power to hydrogen (vol 4, pg 216, 2019). Nat Energy 2019, 4(4): 347-347.

2. Shi QR, Zhu CZ, Du D, Lin YH. Robust noble metal-based electrocatalysts for oxygen evolution reaction. Chem Soc Rev 2019, 48(12): 3181-3192.

3. Reier T, Nong HN, Teschner D, Schlögl R, Strasser P. Electrocatalytic Oxygen Evolution Reaction in Acidic Environments - Reaction Mechanisms and Catalysts. Adv Energy Mater 2017, 7(1): 1601275.

4. Wang J, Cui W, Liu Q, Xing Z, Asiri AM, Sun X. Recent Progress in Cobalt-Based Heterogeneous Catalysts for Electrochemical Water Splitting. Adv Mater 2016, 28(2): 215-230. 
5. Nocera DG. The Artificial Leaf. Acc Chem Res 2012, 45(5): 767-776.

6. Smith PF, Kaplan C, Sheats JE, Robinson DM, McCool NS, Mezle N, et al. What determines catalyst functionality in molecular water oxidation? Dependence on ligands and metal nuclearity in cobalt clusters. Inorg Chem 2014, 53(4): 2113-2121.

7. Li X, Siegbahn PE. Water oxidation mechanism for synthetic Co-oxides with small nuclearity. J Am Chem Soc 2013, 135(37): 13804-13813.

8. Hong S, Pfaff FF, Kwon E, Wang Y, Seo MS, Bill E, et al. Spectroscopic capture and reactivity of a lowspin cobalt(IV)-oxo complex stabilized by binding redox-inactive metal ions. Angew Chem Int Ed Engl 2014, 53(39): 10403-10407.

9. Pfaff FF, Kundu S, Risch M, Pandian S, Heims F, Pryjomska-Ray I, et al. An oxocobalt(IV) complex stabilized by Lewis acid interactions with scandium(III) ions. Angew Chem Int Ed Eng/2011, 50(7): 1711-1715.

10. Dalle KE, Warnan J, Leung JJ, Reuillard B, Karmel IS, Reisner E. Electro- and Solar-Driven Fuel Synthesis with First Row Transition Metal Complexes. Chem Rev 2019, 119(4): 2752-2875.

11. Lyu F, Wang Q, Choi SM, Yin Y. Noble-Metal-Free Electrocatalysts for Oxygen Evolution. Small 2019, 15(1): 1804201.

12. Risch M, Khare V, Zaharieva I, Gerencser L, Chernev P, Dau H. Cobalt-oxo core of a water-oxidizing catalyst film. J Am Chem Soc 2009, 131(20): 6936-6937.

13. McCool NSR, D. M.; Sheats, J. E.; Dismukes, G. C. A Co4O4 "Cubane" Water Oxidation Catalyst Inspired by Photosynthesis. J Am Chem Soc 2011, 133(30): 11446-11449. 
14. Smith PF, Hunt L, Laursen AB, Sagar V, Kaushik S, Calvinho KU, et al. Water Oxidation by the [Co404(OAc)4(py)4](+) Cubium is Initiated by OH(-) Addition. J Am Chem Soc 2015, 137(49): 1546015468.

15. Hadt RG, Hayes D, Brodsky CN, Ullman AM, Casa DM, Upton MH, et al. X-ray Spectroscopic Characterization of Co(IV) and Metal-Metal Interactions in Co404: Electronic Structure Contributions to the Formation of High-Valent States Relevant to the Oxygen Evolution Reaction. J Am Chem Soc 2016, 138(34): 11017-11030.

16. Olshansky L, Huerta-Lavorie R, Nguyen Al, Vallapurackal J, Furst A, Tilley TD, et al. Artificial Metalloproteins Containing Co404 Cubane Active Sites. J Am Chem Soc 2018, 140(8): 2739-2742.

17. Nguyen Al, Wang J, Levine DS, Ziegler MS, Tilley TD. Synthetic control and empirical prediction of redox potentials for Co404 cubanes over a $1.4 \mathrm{~V}$ range: implications for catalyst design and evaluation of high-valent intermediates in water oxidation. Chem Sci 2017, 8(6): 4274-4284.

18. Jiao F, Frei H. Nanostructured Cobalt Oxide Clusters in Mesoporous Silica as Efficient OxygenEvolving Catalysts. Angew Chem Int Ed Eng/ 2009, 48(10): 1841-1844.

19. Brunschwig BS, Chou MH, Creutz C, Ghosh P, Sutin N. Mechanisms of water oxidation to oxygen: cobalt(IV) as an intermediate in the aquocobalt(II)-catalyzed reaction. J Am Chem Soc 1983, 105(14): 4832-4833.

20. Umena Y, Kawakami K, Shen JR, Kamiya N. Crystal structure of oxygen-evolving photosystem II at a resolution of $1.9 \AA$. Nature 2011, 473(7345): 55-60.

21. Brodsky CN, Hadt RG, Hayes D, Reinhart BJ, Li N, Chen LX, et al. In situ characterization of cofacial $\mathrm{Co}(\mathrm{IV})$ centers in $\mathrm{Co} 4 \mathrm{O} 4$ cubane: Modeling the high-valent active site in oxygen-evolving catalysts. Proc Natl Acad Sci U S A 2017, 114(15):3855-3860. 
22. McAlpin JG, Stich TA, Ohlin CA, Surendranath Y, Nocera DG, Casey WH, et al. Electronic structure description of a [Co(III)3Co(IV)04] cluster: a model for the paramagnetic intermediate in cobaltcatalyzed water oxidation. J Am Chem Soc 2011, 133(39): 15444-15452.

23. Nguyen Al, Van Allsburg KM, Terban MW, Bajdich M, Oktawiec J, Amtawong J, et al. Stabilization of reactive $\mathrm{Co} 4 \mathrm{O} 4$ cubane oxygen-evolution catalysts within porous frameworks. Proc Natl Acad Sci U S A 2019, 116: 11630-11639.

24. Nguyen Al, Ziegler MS, Ona-Burgos P, Sturzbecher-Hohne M, Kim W, Bellone DE, et al. Mechanistic Investigations of Water Oxidation by a Molecular Cobalt Oxide Analogue: Evidence for a Highly Oxidized Intermediate and Exclusive Terminal Oxo Participation. J Am Chem Soc 2015, 137(40): 12865-12872.

25. Zhang $M$, de Respinis $M$, Frei $H$. Time-resolved observations of water oxidation intermediates on a cobalt oxide nanoparticle catalyst. Nat Chem 2014, 6(4): 362-367.

26. Andris E, Navratil R, Jasik J, Srnec M, Rodriguez M, Costas M, et al. M-O Bonding Beyond the Oxo Wall: Spectroscopy and Reactivity of Cobalt(III)-Oxyl and Cobalt(III)-Oxo Complexes. Angew Chem Int Ed Eng/2019, 58(28): 9619-9624.

27. Wang B, Lee YM, Tcho WY, Tussupbayev S, Kim ST, Kim Y, et al. Synthesis and reactivity of a mononuclear non- haem cobalt(IV)-oxo complex. Nat Commun 2017, 8.

28. Blakemore JD, Crabtree RH, Brudvig GW. Molecular Catalysts for Water Oxidation. Chem Rev 2015, 115(23): 12974-13005.

29. Liu H, Frei H. Observation of O-O Bond Forming Step of Molecular Co4O4 Cubane Catalyst for Water Oxidation by Rapid-Scan FT-IR Spectroscopy. ACS Catalysis 2020, 10(3): 2138-2147. 
30. Ullman AM, Brodsky CN, Li N, Zheng SL, Nocera DG. Probing Edge Site Reactivity of Oxidic Cobalt Water Oxidation Catalysts. J Am Chem Soc 2016, 138(12): 4229-4236.

31. Brodsky CN, Bediako DK, Shi C, Keane TP, Costentin C, Billinge SJL, et al. Proton-Electron Conductivity in Thin Films of a Cobalt-Oxygen Evolving Catalyst. ACS App/ Energy Mater 2019, 2(1): 3-12.

32. Pasquini C, Zaharieva I, González-Flores D, Chernev P, Mohammadi MR, Guidoni L, et al. H/D Isotope Effects Reveal Factors Controlling Catalytic Activity in Co-Based Oxides for Water Oxidation. J Am Chem Soc 2019, 141(7): 2938-2948.

33. Wang C-C, Chang H-C, Lai Y-C, Fang H, Li C-C, Hsu H-K, et al. A Structurally Characterized Nonheme Cobalt-Hydroperoxo Complex Derived from Its Superoxo Intermediate via Hydrogen Atom Abstraction. J Am Chem Soc 2016, 138(43): 14186-14189.

34. Fukuzumi S, Lee Y-M, Nam W. Structure and reactivity of the first-row d-block metal-superoxo complexes. Dalton T 2019, 48(26): 9469-9489.

35. Farinas E, Baidya N, Mascharak PK. Electron Paramagnetic Resonance Studies on the Formation and Decomposition of the Oxygenated Product of [Coll(PMA)]+, a Synthetic Analog of Cobalt(II) Bleomycin. Inorg Chem 1994, 33(25): 5970-5973.

36. Dimitrou K, Brown AD, Concolino TE, Rheingold AL, Christou G. Mixed-valence, tetranuclear cobalt(,) complexes: preparation and properties of [CoO(OCR)(bpy)] salts. Chem Commun 2001(14): 12841285.

37. Pushkar Y, Davis KM, Palenik M. Model of the Oxygen Evolving Complex Which is Highly Predisposed to 0-O Bond Formation. J Phys Chem Lett 2018, 9: 3524-3531. 
38. Siegbahn PEM. A Structure-Consistent Mechanism for Dioxygen Formation in Photosystem II. Chem Eur J 2008, 14(27): 8290-8302.

39. Yamaguchi K, Shoji M, Isobe H, Yamanaka S, Kawakami T, Yamada S, et al. Theory of chemical bonds in metalloenzymes XXI. Possible mechanisms of water oxidation in oxygen evolving complex of photosystem II. Mol Phys 2018, 116(5-6): 717-745.

40. Yulia Pushkar YP-G, Alireza K. Ravari, Tatiana Otroshchenko, and Daniel A. Hartzler. Mechanism for O-O Bond Formation via Radical Coupling of Metal and Ligand Based Radicals: A New Pathway. J Am Chem Soc 2018, 140(42): 13538-13541.

41. Zhan S, De Gracia Triviño JA, Ahlquist MSG. The Carboxylate Ligand as an Oxide Relay in Catalytic Water Oxidation. J Am Chem Soc 2019, 141(26): 10247-10252.

42. Pantazis DA. The S-3 State of the Oxygen-Evolving Complex: Overview of Spectroscopy and XFEL Crystallography with a Critical Evaluation of Early-Onset Models for O-O Bond Formation. Inorganics 2019, 7(4): 30.

43. Davis KM, Sullivan BT, Palenik MC, Yan L, Purohit V, Robison G, et al. Rapid Evolution of the Photosystem II Electronic Structure during Water Splitting. Phys Rev X 2018, 8(4): 041014.

44. Katherine M. Davis, Brendan T. Sullivan, Mark Palenik, Lifen Yan, Vatsal Purohit, Gregory Robison, et al. Rapid Evolution of the Photosystem II Electronic Structure During Water Splitting. . arXiv:150608862 2015.

45. Suga M, Akita F, Yamashita K, Nakajima Y, Ueno G, Li HJ, et al. An oxyl/oxo mechanism for oxygenoxygen coupling in PSII revealed by an x-ray free-electron laser. Science 2019, 366(6463): 334-+. 
46. Suga M, Akita F, Sugahara M, Kubo M, Nakajima Y, Nakane T, et al. Light-induced structural changes and the site of $\mathrm{O}=0$ bond formation in PSIl caught by XFEL. Nature 2017, 543(7643): 131-135.

47. Kern J, Chatterjee R, Young ID, Fuller FD, Lassalle L, Ibrahim M, et al. Structures of the intermediates of Kok's photosynthetic water oxidation clock. Nature 2018, 563(7731): 421-425.

48. Moonshiram D, Alperovich I, Concepcion JJ, Meyer TJ, Pushkar Y. Experimental demonstration of radicaloid character in a $\mathrm{Ru}-\mathrm{V}=\mathrm{O}$ intermediate in catalytic water oxidation. Proc Natl Acad Sci U S A 2013, 110(10): 3765-3770.

49. Siegbahn PEM. Water oxidation mechanism in photosystem II, including oxidations, proton release pathways, 0-0 bond formation and 0-2 release. Biochim Biophys Acta-Bioenerg 2013, 1827(8-9): 1003-1019.

50. Ezhov R, Ravari AK, Pushkar Y. Characterization of the FeV=0 Complex in the Pathway of Water Oxidation. Angew Chem Int Ed Engl 2020, 59(32): 13502-13505.

\section{Figures}

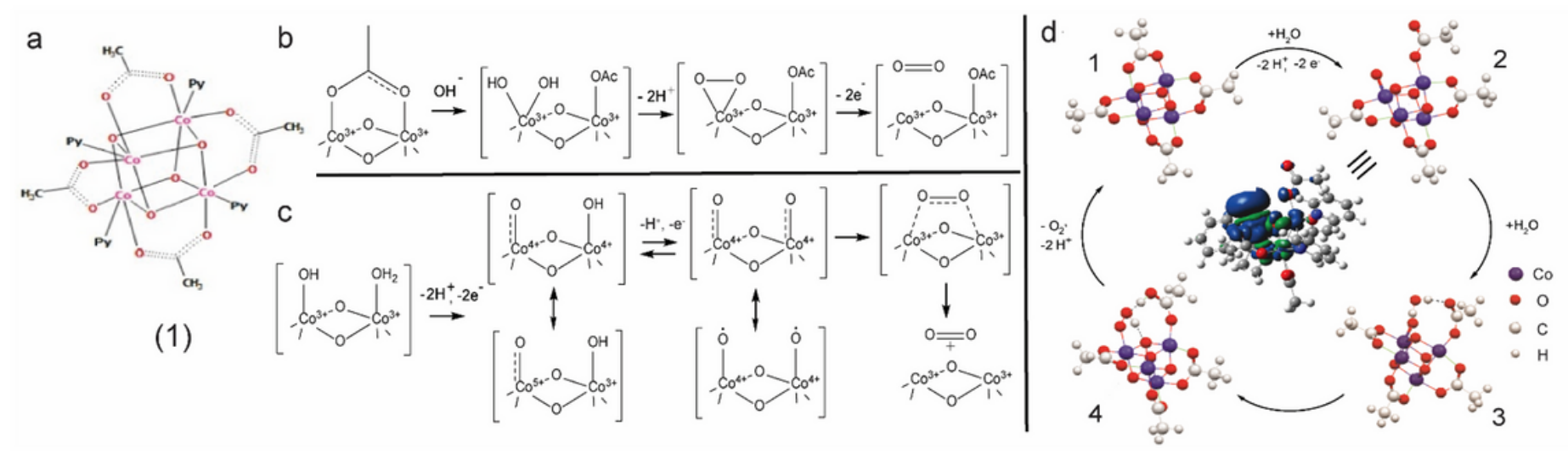

\section{Figure 1}

(a) Structure of the [Co404Py4Ac4]0 (1) water oxidation catalyst. (b) 0-0 bond formation via germinal hydroxide on Co cen-ter 14. (c) 0-0 bond formation via radical coupling at adjacent Co centers in high oxidation state.21, 23 (d) Water nucleophilic attack mechanism proposed in this study of (1) - catalyzed 
WOR during bulk electrolysis at $\mathrm{pH}=12$. In the middle is DFT model of the [Colll2O4ColV=0/ColV(CH3CO2)mono]0 active intermediate with a spin-density distribution showing strong radica-loid character of the ColV $=0$ unit. Peroxide formation is facilitated by two hydrogen bonds with the carboxyl accepting a pro-ton and a bridging oxygen stabilizing the peroxide.
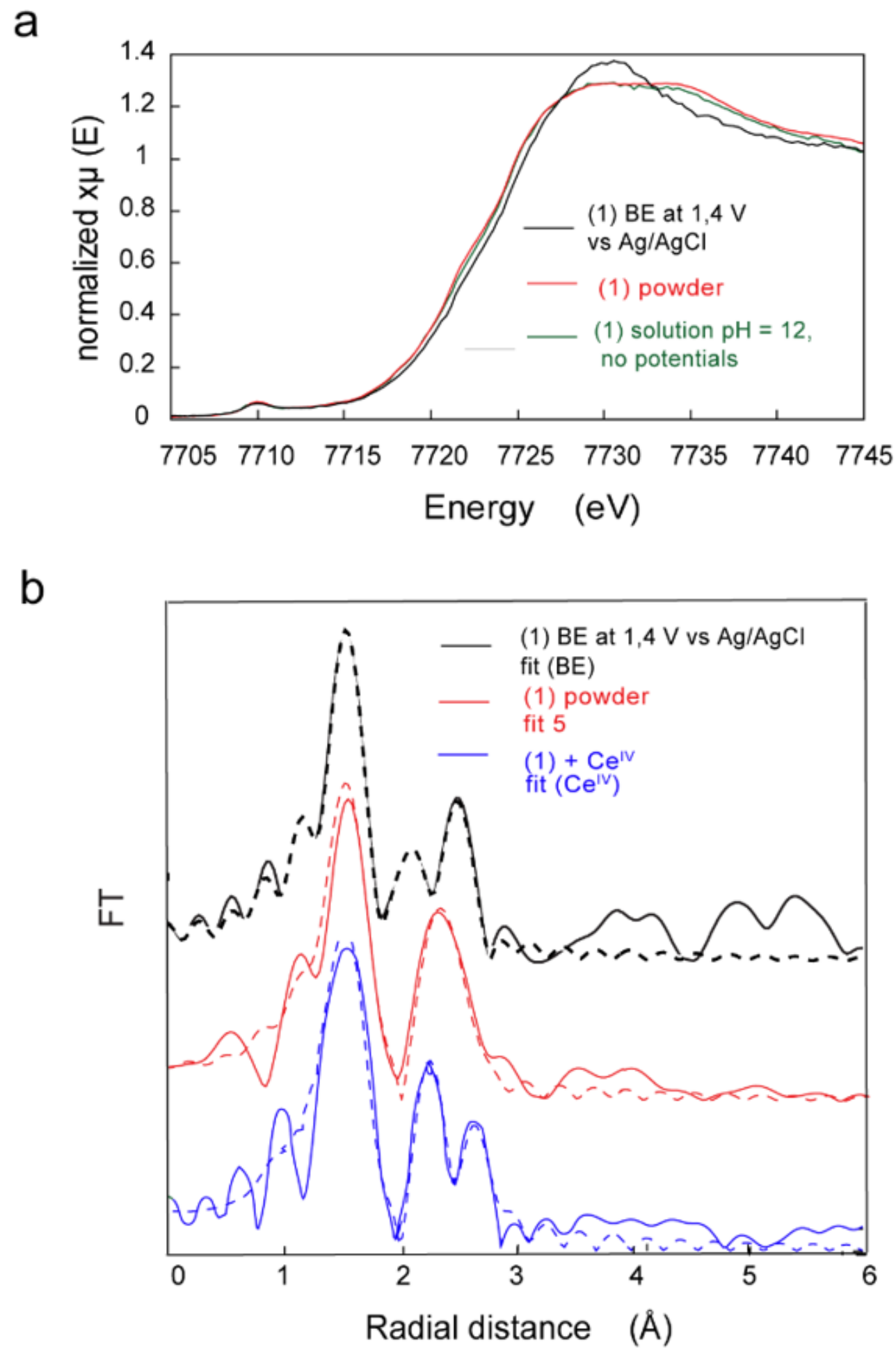

Figure 2 
XAS spectroscopy of (1) and its oxidized intermediates. (a) Co K-edge XANES of (1) as a starting powder (red), its solution at $\mathrm{pH}=12$ before $\mathrm{BE}$ electrolysis (green), and its solution during the electrolysis at $\mathrm{pH}=$ 12 with $1.4 \mathrm{~V}$ poten-tial vs $\mathrm{Ag} / \mathrm{AgCl}$ after prolonged time (black). (b) EXAFS data and corresponding best fits (Tables 1 and S3) of (1) as a powder (red), its solution during BE electrolysis and its solution oxidized with CelV (blue) and measured in a cryo-stat (20K).

a

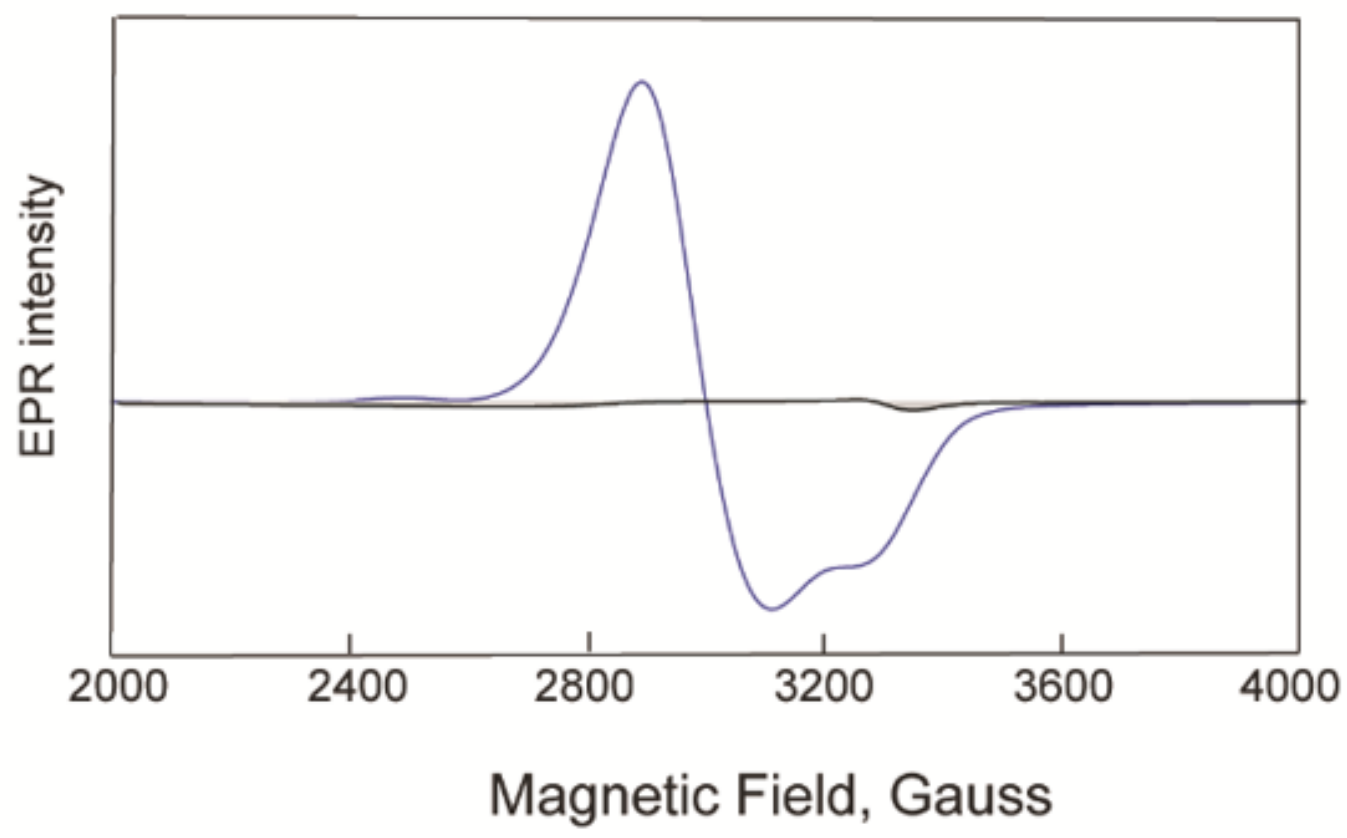

b

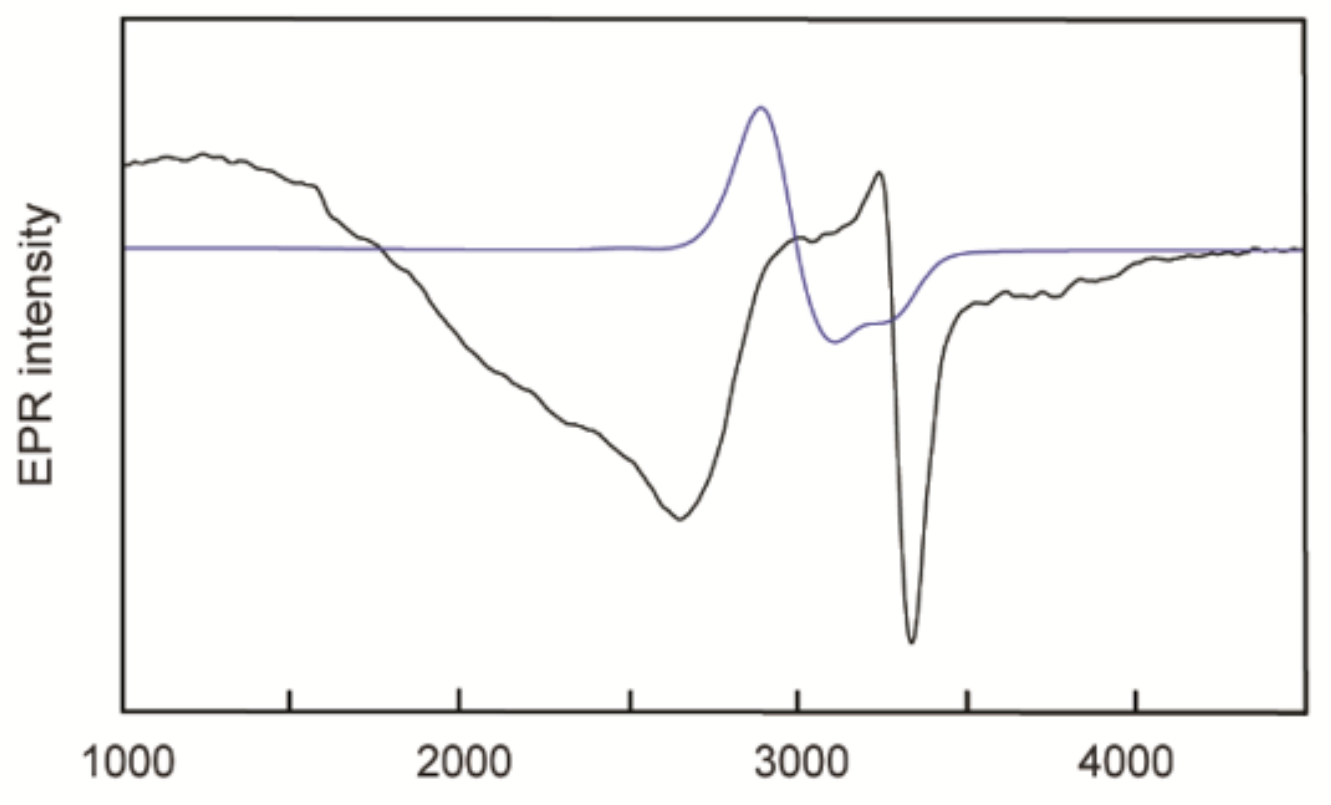

Magnetic Field, Gauss

Figure 3 
X-Band EPR (20 K) of $1 \mathrm{mM}$ solution of (1)+ (blue) in com-parison with $1 \mathrm{mM}$ solution of (1) (black) subjected to bulk electrolysis at $\mathrm{pH}=12$ with $1.4 \mathrm{~V}$ potential vs $\mathrm{Ag} / \mathrm{AgCl}$ after prolonged time (black) and quickly frozen for EPR analy-sis. (a) The spectra are presented on the same intensity scale; (b) The same comparison but intensity of BE EPR is magnified in 100 times.

a

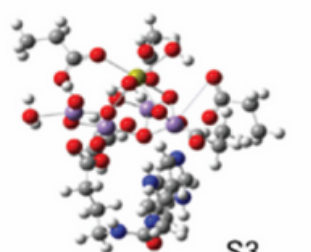

S3

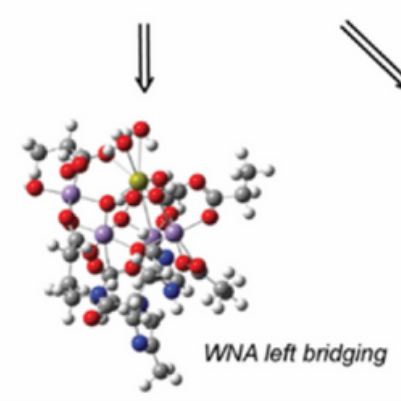

b

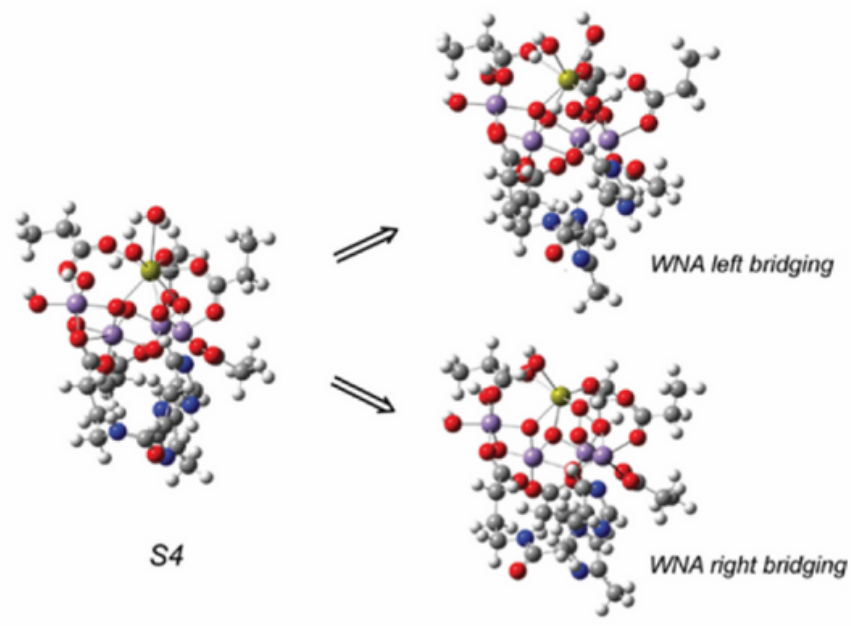

Figure 4

Models of the PSII OEC at S3 (a) and S4 (b) states. Structures of the peroxides formed via radical coupling and WNA are shown.

\section{Supplementary Files}

This is a list of supplementary files associated with this preprint. Click to download.

- SIPushkar110920.docx 